\title{
VARIAN SOMAKLONAL KACANG TANAH RESISTEN SCLEROTIUM ROLFSII HASIL SELEKSI IN VITRO MENGGUNAKAN FILTRAT KULTUR CENDAWAN
}

\author{
Yusnita $^{1 *}$, Hajrial Aswidinnoor ${ }^{1}$, Rita Megia², Rusmilah Suseno ${ }^{3}$ \& Sudarsono ${ }^{1}$
}

\begin{abstract}
Peanut somaclonal variants resistant to Sclerotium rolfsii derived from in vitro selection with fungal culture filtrates. Sclerotium stem rot is one of the most important peanut disease which often caused significant yield loss. The use of peanut cultivars resistant to Sclerotium rolfsii infection is the most efficient way to control the disease. Attempts to obtain peanut lines with tolerance or resistance to Sclerotium stem rot through induction of somaclonal variation and in vitro selection using fungal culture filtrates (CF) have been conducted previously. Somatic embryo (SE) clumps that had been maitained in culture for approximately one year in regeneration medium were exposed onto selective medium containing $30 \% \mathrm{~S}$. rolfsii $\mathrm{CF}$ for three consecutive 1 month -passages, and the SE formed after selection periods were considered to be insensitive to the fungal CF. A number R0 peanut lines have been regenerated from CF-insensitive SE, and their R1 and R2 progenies were grown in a plastic house for evaluation on qualitative and quantitative variant characters. Early identification for tolerance to $S$. rolfsii was also conducted among R0 peanut lines, and the results have shown enhanced resistance when compared to the original non-selected cultivar. However, further evaluation is needed to study responses of the R1 and R2 progenies of the somaclones against $S$. rolfsii infection. The objective of this particular study was to evaluate responses of R1 and R2 peanut somaclones derived from fungal CF-insensitif SE against $S$. rolfsii infection in the plastic house. Results of this experiment showed, a number of resistant somaclonal variants were obtained among R1 and R2 population, which segregated as resistance and susceptible to $S$. rolfsii infection. The resistance somaclonal variants initially showed stem rot symptoms after inoculation with $S$. rolfsii with disease score (DS) of 1 to 3 . However, as the plants grew and developed, they showed wound-healing process at the lesio and they were able to produce the same or higher number of filled pod as the original non-inoculated peanut plants.
\end{abstract}

Key words: Somaclonal variation, in vitro selection, Sclerotium rolfsii, fungal culture filtrates, disease resistance, peanut

\section{PENDAHULUAN}

Kemungkinan untuk menginduksi variasi somaklonal di antara tanaman yang diregenerasikan melalui kultur sel dan jaringan telah menimbulkan minat yang tinggi untuk menggunakannya sebagai salah satu cara untuk membantu pemuliaan tanaman (Larkin \& Scowcroft, 1981). Beberapa penelitian terdahulu menunjukkan bahwa teknik tersebut telah berhasil digunakan untuk mendapatkan plasma nutfah yang toleran atau resisten terhadap penyakit tertentu (Daub, 1986; Hammerschlag, 1992).
Pemuliaan tanaman untuk sifat resistensi terhadap penyakit tertentu merupakan salah satu cara untuk melindungi tanaman dari kerusakan oleh faktor biotik, khususnya oleh mikroorganisme patogen. Karakter resisten penyakit yang dapat diturunkan sangat penting dalam budidaya tanaman karena dapat menghemat biaya produksi secara nyata. Beberapa penyakit tanaman sangat merusak dan tersebar di areal pertanaman yang luas, sehingga menjadi prioritas utama bagi pemulia untuk mendapatkan varietas baru yang resisten.

\footnotetext{
1 Laboratorium Biologi Molekuler Tanaman, Departemen Agronomi dan Hortikultura, Fakultas Pertanian, Institut Pertanian Bogor (IPB). E-mail: yusnita.said@yahoo.com; yusnita@unila.ac.id

2 Departemen Biologi, Fakultas MIPA, Institut Pertanian Bogor, Jl. Kamper Kampus Darmaga, Bogor 16680

3 Departemen Proteksi Tanaman, Fakultas Pertanian, Institut Pertanian Bogor, Jl. Kamper Kampus Darmaga, Bogor 16680

* Alamat sekarang: Jurusan Budidaya Pertanian, Fakultas Pertanian, Universitas Lampung,

Jl. Sumantri Brojonegoro No.1 Bandar Lampung 35145
} 
Busuk batang Sclerotium merupakan salah satu penyakit penting pada tanaman kacang tanah, yang seringkali menyebabkan kehilangan hasil yang tinggi. Penyakit ini disebabkan oleh cendawan tular-tanah Sclerotium rolfsii Sacc. Penyakit yang menyebabkan kebusukan pada pangkal batang kacang tanah dan seringkali penyebab kematian atau kerusakan yang parah ini relatif sulit diberantas, karena cendawan patogennya mempunyai inang beragam dan dapat membentuk sklerosia yang mampu bertahan hidup di dalam tanah dalam waktu lama (Punja et al., 1985).

Varietas atau genotipe kacang tanah yang ada di Indonesia dilaporkan belum ada yang tahan terhadap infeksi cendawan ini (Rani, 2001; Widyanti, 2001; Yusnita $\&$ Sudarsono, 2004). Untuk itu dilakukan upaya untuk mendapatkan plasma nutfah kacang tanah yang toleran atau resisten terhadap penyakit busuk batang Sclerotium melalui induksi keragaman somaklonal dan seleksi in vitro menggunakan filtrat kultur $S$. rolfsii (Yusnita et al., 2005). Dalam penelitian tersebut, kalus embriogenik yang telah dipelihara selama kurang lebih satu tahun dalam media regenerasi dikulturkan dalam medium MS (Murashige \& Skoog, 1962) dengan penambahan 30\% filtrat kultur $S$. rolfsii, dan ES yang terbentuk setelah tiga periode seleksi in vitro masing-masing selama satu bulan, dianggap sebagai insensitif terhadap filtrat kultur cendawan.

Sejumlah galur kacang tanah R0 telah diregenerasikan dari embrio somatik yang insensitif terhadap filtrat kultur cendawan, dan zuriat R1 dan R2nya telah ditanam di rumah plastik dan dievaluasi untuk berbagai karakter kualitatif dan kuantitatifnya (Yusnita et al., 2005). Hasil penelitian tersebut menunjukkan bahwa terdapat beragam karakter varian morfologis, fisiologis dan agronomis diantara tanaman somaklon hasil seleksi in vitro. Evaluasi untuk resistensi terhadap infeksi $S$. rolfsii juga telah dilakukan secara dini pada galur-galur somaklon generasi R0, yang mengindikasikan peningkatan ketahanannya dibandingkan dengan populasi tanaman kacang tanah awal (Yusnita et al., 2006). Penelitian ini bertujuan untuk mengevaluasi respons ketahanan galur-galur somaklon kacang tanah hasil seleksi in vitro generasi R1 dan R2 terhadap infeksi S. rolfsii.

\section{METODE PENELITIAN}

Penelitian ini terdiri dari serangkaian percobaan yang dilakukan di rumah plastik Departemen Agronomi Institut Pertanian Bogor, dari bulan Februari 2004 sampai dengan Februari 2005.
Regenerasi ES Insensitif Filtrat Kultur Cendawan menjadi Galur-Galur Tanaman R0. Dari hasil seleksi in vitro1500 clump kalus embriogenik menggunakan $30 \%$ filtrat kultur cendawan, telah didapatkan sebanyak kurang lebih 1-2 ES insensitif filtrat kultur cendawan pada sekitar 300 clump. Perbandingan jumlah ES hasil seleksi in vitro tersebut hanya 1-5\% dari ES tanpa seleksi in vitro (Yusnita et al., 2005). Untuk proses pemulihan dan proliferasinya, ES hasil seleksi in vitro ditransfer ke media MS (Murashige \& Skoog, 1962) dengan penambahan pikloram $16 \mu \mathrm{M}$ (P16). Selanjutnya, maturasi dan pengecambahan ES dilakukan dengan mentransfernya ke media MS dengan penambahan arang aktif $2 \mathrm{~g} \mathrm{l}^{-1}$ (MSAC) selama dua periode pengulturan, masing-masing satu bulan. Untuk merangsang pertumbuhan epikotil dan pemanjangan tunas, ES yang berkecambah dipotong akarnya dan ditanam selama kurang lebih 2 minggu dalam medium MS dengan penambahan kombinasi BAP $2 \mathrm{mg} \mathrm{l}^{-1}$ dan kinetin $2 \mathrm{mg} \mathrm{l}^{-1}$.

Untuk mendapatkan planlet, tunas ditanam kembali dalam media MSAC hingga berakar. Aklimatisasi planlet dilakukan secara bertahap dengan menanamnya di pot plastik berisi campuran pasir dan arang sekam steril $(1: 1, \mathrm{v} / \mathrm{v})$ yang disungkup dengan kantong plastik, hingga mampu bertahan hidup di rumah plastik. Tanaman R0 yang mampu bertahan hidup dari tahapan aklimatisasi selanjutnya ditanam dalam polybag dengan ukuran $45 \mathrm{~cm} \times 45 \mathrm{~cm}$ yang berisi $10 \mathrm{~kg}$ campuran tanah:pasir:kompos $(1: 1: 1, \mathrm{v} / \mathrm{v})$ dan dipelihara di rumah plastik Fakultas Pertanian, IPB, Bogor. Penyiraman, pemupukan (pupuk majemuk NPK [15:15:15]), dan pengendalian hama, penyakit dan gulma dilakukan sesuai kebutuhan hingga tanaman dapat dipanen. Benih R0:1 dipanen secara terpisah dari masingmasing nomor tanaman R0 dan dikeringkan.

Penanaman Tanaman Somaklon R1 dan R2 di Rumah Plastik. Tanaman R1 ditumbuhkan dari benih R0:1 zuriat dari 25 tanaman R0 yang masing-masing diregenerasikan dari ES hasil seleksi in vitro. Dari setiap nomor tanaman R0 ditanam 1 hingga 20 tanaman R1 zuriatnya, bergantung dari jumlah polong bernas yang dihasilkan sebelumnya. Penanaman benih R0:1 di rumah plastik dan pemeliharaannya dilakukan di polybag sebagaimana dijelaskan sebelumnya untuk tanaman R0. Tanaman R1 dipelihara hingga panen, dan benih R1:2 yang dihasilkan dipanen secara terpisah dari masingmasing nomor tanaman R1, kemudian dikeringkan dan pada musim berikutnya ditanam di rumah plastik sebagaimana tanaman R1. 
Tanaman R2 ditumbuhkan dari benih R1:2, zuriat dari masing-masing nomor tanaman R1 terpilih. Dari setiap tanaman R1 dipilih satu nomor yang menghasilkan polong bernas paling banyak, dan dari masing-masing nomor R1 tersebut ditanam minimal 10 tanaman R2. Tanaman R2 ditumbuhkan di rumah plastik dengan cara dan pemeliharaan sebagaimana dijelaskan sebelumnya untuk tanaman R0 dan R1. Tanaman R2 dipelihara hingga panen, benih R2:3 dipanen secara terpisah dari masing-masing nomor tanaman R2, lalu dikeringkan.

Tanaman kacang tanah cv. Kelinci (tanaman awal) yang tidak melalui tahapan seleksi in vitro ditumbuhkan dari benih di rumah plastik menggunakan polybag dengan media tumbuh dan cara pemeliharaan yang sama dengan sebelumnya. Tanaman awal tersebut digunakan sebagai pembanding untuk tanaman R0. Sebagai pembanding untuk tanaman R1 dan R2, ditanam zuriat pertama dan kedua tanaman awal dengan cara, pemeliharaan dan dalam lingkungan yang sama.

\section{Pembuatan Isolat $S$. rolfsii dan Inokulasi pada} Tanaman Somaklon R1 dan R2. Cendawan $S$. rolfsii yang virulensinya telah diuji, diisolasi dari tanaman kacang tanah terinfeksi Sclerotium di Kebun Percobaan IPB - Babakan Sawah Baru, Darmaga, Bogor. Isolat cendawan diperbanyak dalam media potato dextrose agar (PDA) dan diinkubasi dalam ruang bersuhu $26^{\circ} \mathrm{C}$ selama 6-7 hari, sehingga mempunyai koloni hifa yang tebal tetapi belum membentuk sklerosia. Hifa dari kultur cendawan dalam media PDA padat seluas $1 \mathrm{~cm}^{2}$ digunakan sebagai inokulum untuk menginokulasi tanaman kacang tanah generasi R1 dan R2. Tanaman somaklon R1 dan R2 dan tanaman kacang tanah cv. Kelinci awal sebagai kontrol diinokulasi pada umur 4 minggu setelah tanam.

Pada generasi R1, inokulasi hanya dilakukan pada masing-masing 3 tanaman untuk 5 nomor galur R0 (SC+INO), dan 2 tanaman cv. Kelinci awal sebagai kontrol (SD+INO). Sejumlah 144 tanaman R1 hasil seleksi in vitro yang lain tidak diinokulasi (SC-INO), sedangkan 8 tanaman cv. Kelinci awal digunakan sebagai kontrol tanpa inokulasi (SD-INO). Pada generasi R2, inokulasi dilakukan pada setiap nomor galur R1 yang ditanam, masing-masing 5 dari 10 tanaman (SC+INO). Lima tanaman sisanya dari masing-masing galur R1 digunakan sebagai kontrol somaklon tanpa inokulasi (SCINO). Sebanyak 12 tanaman cv. Kelinci awal digunakan sebagai kontrol yang diinokulasi (SD+INO), dan 10 tanaman tanpa inokulasi (SD-INO). Inokulasi pada semua tanaman yang diuji dilakukan dengan cara menusuk pangkal batang, masing-masing sebanyak 5 tusukan dengan jarum steril, kemudian menempelkan inokulum berupa miselia dan menimbunnya dengan tanah.

Skoring Gejala Penyakit akibat Infeksi $S$. rolfsii. Pengamatan gejala penyakit dilakukan 14 hari setelah tanaman diinokulasi. Skor gejala penyakit busuk batang pada tanaman kacang tanah yang diinokulasi dicatat sesuai perkembangan infeksi cendawan yang terjadi pada pangkal batang tanaman yang diuji. Gejala infeksi S. rolfsii yang berkembang diberi nilai skor antara $0-5$, sebagaimana dijelaskan oleh Yusnita \& Sudarsono (2004). Kriteria nilai skor gejala penyakit busuk batang Sclerotium adalah: skor $0=$ tanaman sehat, tidak menunjukkan gejala, skor $1=$ gejala nekrosis dengan luasan hingga $1 / 2$ lingkar batang, skor $2=$ gejala nekrosis antara $1 / 2-3 / 4$ lingkar batang, skor $3=$ gejala nekrosis telah melingkari batang, bercak cokelat telah meluas, dan kulit batang kadang-kadang sobek, skor $4=$ seperti skor 3 , batang yang terserang mulai terkulai dan sebagian daun layu, dan skor $5=$ tanaman mati.

\section{Pengamatan untuk Karakter Kuantitatif setelah} Inokulasi. Pada semua tanaman yang diuji, baik yang tidak diinokulasi maupun yang diinokulasi (kecuali untuk tanaman yang mati setelah diinokulasi) dilakukan pengamatan untuk peubah kuantitatif, yang meliputi tinggi tanaman, jumlah cabang pada batang utama, jumlah polong cipo dan jumlah polong bernas per tanaman. Pengamatan untuk peubah kuantitatif tersebut dilakukan setelah tanaman dipanen.

\section{HASIL DAN PEMBAHASAN}

Perkembangan Gejala Penyakit Busuk Batang setelah Diinokulasi $S$. rolfsii. Semua tanaman somaklon yang diinokulasi menunjukkan gejala penyakit dengan tingkat keparahan yang berbeda antara skor 1 sampai 5, sedangkan semua tanaman awal yang diinokulasi mati (skor 5). Baik tanaman awal maupun somaklon yang tidak diinokulasi tidak menunjukkan gejala penyakit (skor 0). Secara umum, gejala mulai muncul pada pangkal batang yang diinokulasi 5-8 hari setelah inokulasi. Gejala penyakit busuk batang dimulai dengan munculnya lesio pada batang yang diselimuti miselia $S$. rolfsii berwarna putih. Lesio tersebut semakin melebar dengan berjalannya waktu setelah inokulasi disertai dengan pembusukan permukaan batang. Bertambah luasnya lesio pada batang diikuti oleh terjadinya perubahan warna batang pada tepi lesio dari coklat muda menjadi coklat tua. Pada hari ke 10-14, 
bintik-bintik sklerosia berwarna putih kecoklatan mulai terbentuk di permukaan batang yang membusuk. Setelah pembusukan batang meluas dan pembentukan sklerosia dari hifa cendawan terjadi, sebagian daun pada cabang utama mulai layu. Pada sejumlah somaklon dan semua tanaman awal yang diinokulasi dengan $S$. rolfsii, gejala tersebut berlanjut dengan kematian tanaman. Pada sejumlah tanaman somaklon yang diinokulasi, gejala penyakit busuk batang tetap muncul, tetapi lamakelamaan miselia cendawan tidak berkembang dan pembusukan batang tidak berlanjut. Tanaman somaklon tersebut terinfeksi, tetapi menunjukkan resistensi terhadap penyakit yang ditandai dengan terjadinya proses penyembuhan luka pada lesio di bagian batang yang terinfeksi, seiring dengan pertumbuhan tanaman. Proses penyembuhan luka pada lesio tersebut ditandai dengan pembentukan kalus, mirip seperti pada batang yang dicangkok. Di samping itu, pembentukan bunga, ginofor dan polong bernas tetap terjadi pada tanaman-tanaman somaklon terinfeksi, terutama pada tanaman bergejala penyakit dengan skor 1-3. Tanaman dengan skor 4 umumnya tidak mampu menghasilkan polong bernas, walaupun masih hidup hingga saat panen.

Dari setiap10 tanaman somaklon R2 zuriat dari masing-galur R1 terpilih, lima tanaman yang tidak diinokulasi semuanya tidak bergejala penyakit (skor 0), sedangkan 5 tanaman yang diinokulasi menunjukkan gejala beragam mulai dari skor 1 hingga skor 5 . Semua tanaman awal yang diinokulasi menunjukkan gejala penyakit dan pada hari ke-14 setelah inokulasi, semua tanaman mati.

\section{Respons Somaklon R1 terhadap Inokulasi} S. rolfsii. Respons tanaman R1 zuriat dari 6 galur tanaman R0 terhadap inokulasi $S$. rolfsii disajikan pada Tabel 1. Pada Tabel 1 terlihat bahwa semua tanaman awal yang tidak diinokulasi (SD-INO) maupun semua tanaman somaklon yang tidak diinokulasi (SC-INO) menunjukkan skor 0 atau tidak menunjukkan gejala penyakit, sedangkan semua tanaman awal yang diinokulasi (SD+INO) menunjukkan gejala penyakit dengan skor 5 (tanaman mati). Sebaliknya, tanaman somaklon yang diinokulasi (SC+INO) menunjukkan gejala penyakit dengan skor beragam mulai dari skor 2 (4 tanaman), skor 3 (6 tanaman), skor 4 (4 tanaman), dan skor 5 (4 tanaman).

Respons Somaklon R2 terhadap Inokulasi $S$. rolfsii. Respons tanaman somaklon $\mathrm{R} 2$ zuriat dari setiap galur tanaman R1 terpilih terhadap inokulasi $S$. rolfsii disajikan pada Tabel 2. Pada Tabel 2 terlihat bahwa semua tanaman awal yang tidak diinokulasi (SD-INO)

Tabel 1. Respons tanaman R1-zuriat dari galur somaklon R0 hasil seleksi in vitro (SC) terhadap inokulasi dengan $S$. rolfsii dibandingkan dengan tanaman kacang tanah awal (SD) yang tidak melalui seleksi in vitro

\begin{tabular}{ccccc}
\hline \multirow{2}{*}{$\begin{array}{c}\text { Skor gejala } \\
\begin{array}{c}\text { penyakit busuk } \\
\text { batang }\end{array}\end{array}$} & $\begin{array}{c}\text { Frekuensi tanaman awal (SD) } \\
\text { berdasarkan skor gejala penyakit }\end{array}$ & $\begin{array}{c}\text { Frekuensi somaklon (SC) berdasarkan } \\
\text { skor gejala penyakit }\end{array}$ \\
\cline { 2 - 5 } & $\begin{array}{c}\text { Tanpa inokulasi } \\
\text { (SD-INO) }\end{array}$ & $\begin{array}{c}\text { Setelah inokulasi } \\
\text { dengan S. rolfsii } \\
\text { (SD+INO) }\end{array}$ & $\begin{array}{c}\text { Tanpa inokulasi } \\
\text { (SC-INO) }\end{array}$ & $\begin{array}{c}\text { Setelah inokulasi } \\
\text { dengan S. rolfsii } \\
\text { (SC+INO) }\end{array}$ \\
\hline 0 & 8 & 0 & 144 & 0 \\
1 & 0 & 0 & 0 & 0 \\
2 & 0 & 0 & 0 & 4 \\
3 & 0 & 0 & 0 & 6 \\
4 & 0 & 0 & 0 & 4 \\
5 & 0 & 2 & 0 & 18 \\
Jumlah tanaman & 8 & 2 & 144 & 4 \\
yang diamati & & &
\end{tabular}


maupun semua tanaman somaklon yang tidak diinokulasi (SC-INO) menunjukkan skor 0 atau tidak bergejala penyakit, sedangkan semua tanaman awal yang diinokulasi (SD+INO) menunjukkan gejala penyakit dengan skor 5, atau tanaman mati.

Sebaliknya, pada 158 tanaman somaklon yang diinokulasi ( $\mathrm{SC}+\mathrm{INO})$ diamati gejala penyakit dengan skor beragam mulai dari skor 1 (13 tanaman), skor 2 (15 tanaman), skor 3 (38 tanaman), skor 4 (8 tanaman), dan skor 5 (84 tanaman). Secara lebih rinci, respons somaklon R2 zuriat dari masing-masing nomor R1 terpilih terhadap inokulasi $S$. rolfsii berdasarkan skor gejala penyakit yang muncul pada hari ke 14 setelah inokulasi dapat dilihat pada Tabel 3 .

Segregasi antara Resisten dan Rentan pada Populasi Somaklon. Hasil penelitian ini menunjukkan bahwa baik pada generasi R1 maupun R2, respons tanaman somaklon kacang tanah hasil seleksi in vitro dengan filtrat kultur cendawan terhadap infeksi $S$. rolfsii bersegregasi untuk tingkat keparahan penyakit antara skor 1-4 (tanaman masih hidup) dengan skor 5 (tanaman mati). Karena tanaman dengan gejala penyakit pada skor 4 umumnya tidak mampu menghasilkan polong bernas, maka tanaman terinfeksi yang dianggap resisten penyakit busuk batang Sclerotium adalah yang bergejala dengan skor 1-3.
Pada somaklon generasi R1 yang diinokulasi, frekuensi tanaman dengan gejala penyakit skor 2 sebanyak 4 tanaman, sedangkan skor 3 sebanyak 6 tanaman. Dengan kata lain, 56\% somaklon R1 menunjukkan respons resisten terhadap infeksi $S$. rolfsii (Tabel 1). Dari 10 tanaman R1 yang resisten dan zuriat R2-nya ditanam untuk diinokulasi, 6 galur diantaranya menghasilkan zuriat R2 yang resisten dengan skor 1-3, sedangkan 4 galur (K1.14-SC, K10.12-SC, K13.13-SC, dan K26.8-SC) zuriat R2-nya rentan, hampir semuanya mati dengan skor 5 (Tabel 3, dengan tanda*). Hal ini mengindikasikan adanya konsistensi dalam respons resistensi tanaman somaklon hasil seleksi in vitro terhadap infeksi $S$. rolfsii, yaitu bahwa somaklon kacang tanah hasil seleksi in vitro dengan filtrat kultur cendawan menunjukkan gejala resistensi terhadap penyakit busuk batang Sclerotium, baik pada generasi R1 maupun R2.

Pada generasi R2, dari 158 somaklon zuriat dari 34 galur R1 terpilih (termasuk 10 galur R1 yang resisten) yang diinokulasi dengan $S$. rolfsii, 84 tanaman mati dengan skor 5 (53\%), 8 tanaman menunjukkan gejala penyakit dengan skor 4 dan tidak menghasilkan polong, sedangkan 66 tanaman sisanya (42\%) menunjukkan gejala resisten. Dengan demikian, dari serangkaian percobaan yang telah dilakukan sebelumnya (Yusnita et al., 2005; Yusnita et al., 2006) yang dilanjutkan dengan percobaan ini, telah didapatkan tanaman somaklon

Tabel 2. Respons tanaman R2-zuriat dari galur somaklon R1 terpilih hasil seleksi in vitro (SC) terhadap inokulasi dengan $S$. rolfsii dibandingkan dengan tanaman kacang tanah awal (SD) yang tidak melalui seleksi in vitro

\begin{tabular}{ccccc}
\hline \multirow{2}{*}{$\begin{array}{c}\text { Skor gejala } \\
\text { penyakit busuk } \\
\text { batang }\end{array}$} & $\begin{array}{c}\text { Frekuensi tanaman awal (SD) } \\
\text { berdasarkan skor gejala penyakit }\end{array}$ & $\begin{array}{c}\text { Frekuensi somaklon (SC) berdasarkan } \\
\text { skor gejala penyakit }\end{array}$ \\
\cline { 2 - 5 } & $\begin{array}{c}\text { Tanpa inokulasi } \\
\text { (SD-INO) }\end{array}$ & $\begin{array}{c}\text { Setelah inokulasi } \\
\text { dengan S. rolfsii } \\
\text { (SD+INO) }\end{array}$ & $\begin{array}{c}\text { Tanpa inokulasi } \\
\text { (SC-INO) }\end{array}$ & $\begin{array}{c}\text { Setelah inokulasi } \\
\text { dengan S. rolfsii } \\
\text { (SC+INO) }\end{array}$ \\
\hline 0 & 10 & 0 & 152 & 0 \\
1 & 0 & 0 & 0 & 13 \\
2 & 0 & 0 & 0 & 15 \\
3 & 0 & 0 & 0 & 38 \\
4 & 0 & 0 & 0 & 84 \\
5 & 0 & 12 & 0 & 158 \\
\hline Jumlah tanaman & 10 & 12 & 152 & \\
yang diamati & & & & \\
\hline
\end{tabular}


Tabel 3. Respons masing-masing galur R1 terhadap inokulasi $S$. rolfsii berdasarkan skor gejala penyakit yang ditimbulkan pada zuriat R2-nya dibandingkan dengan kacang tanah cv. Kelinci sebagai tanaman awal

\begin{tabular}{|c|c|c|c|c|c|c|}
\hline \multirow[t]{2}{*}{ Nomor Galur R1 } & \multicolumn{5}{|c|}{$\begin{array}{l}\text { Tanaman diinokulasi } S . \text { rolfsii } \\
\text { (SC+INO) }\end{array}$} & \multirow{2}{*}{$\begin{array}{l}\% \text { Tanaman } \\
\text { yang hidup }\end{array}$} \\
\hline & \multicolumn{5}{|c|}{ Skor gejala penyakit akibat infeksi $S$. rolfsii } & \\
\hline SD+INO & 5 & 5 & 5 & 5 & 5 & 0 \\
\hline K1.13-SC & 4 & 4 & 3 & 5 & 5 & 60 \\
\hline $\mathrm{K} 1.11-\mathrm{SC}^{*}$ & 4 & $3^{* *}$ & 5 & - & - & - \\
\hline K1.14-SC* & 4 & 5 & 5 & 5 & 5 & 20 \\
\hline K3.1-SC* & 3 & 5 & 5 & 5 & 2 & 40 \\
\hline K3.4-SC & 2 & 2 & $1 * *$ & 3 & $1 * *$ & 100 \\
\hline $\mathrm{K} 3.12-\mathrm{SC}^{*}$ & 5 & 2 & 5 & 5 & 5 & 20 \\
\hline K3.10-SC* & 3 & 5 & 3 & 5 & - & 50 \\
\hline K4.3-SC & 5 & 3 & 3 & 3 & 5 & 60 \\
\hline K5.2-SC & 1 & 5 & 3 & 5 & $1 * *$ & 60 \\
\hline K5.7-SC* & 1 & 5 & 5 & 3 & - & 50 \\
\hline K6.3-SC & 5 & 5 & 3 & 4 & 4 & 60 \\
\hline K7.1-SC & 5 & 2 & 3 & $3 * *$ & $3 * *$ & 80 \\
\hline K8.2-SC & 2 & 5 & 2 & 1 & 1 & 80 \\
\hline K9.2-SC & 5 & 5 & 5 & 5 & 5 & 0 \\
\hline K10.15-SC & 5 & 3 & 3 & $3 * *$ & 3 & 80 \\
\hline K10.12-SC* & 5 & 5 & 5 & - & - & 0 \\
\hline K11.2-SC & 2 & 5 & 5 & 5 & 3 & 40 \\
\hline K12.2-SC & 5 & 3 & $1 * *$ & 5 & 5 & 40 \\
\hline K13.6-SC & 5 & 4 & 3 & 3 & 5 & 60 \\
\hline K13.13-SC* & 5 & 5 & 5 & 5 & - & 0 \\
\hline K14.2-SC & 3 & $3 * *$ & 5 & 5 & $3 * *$ & 60 \\
\hline K15.1-SC & 5 & 5 & 3 & 5 & $2 * *$ & 40 \\
\hline K18.2-SC & 5 & $3^{* *}$ & $2 * *$ & 5 & 5 & 60 \\
\hline K19.3-SC & 2 & 5 & 5 & 5 & 5 & 20 \\
\hline K20.1-SC & 5 & $2 * *$ & 5 & 3 & 4 & 60 \\
\hline K21.1-SC & 5 & 5 & 3 & 1 & 1 & 60 \\
\hline K22.4-SC & 3 & 5 & $1 * *$ & 1 & 5 & 80 \\
\hline K24.1-SC & 5 & 5 & $2 * *$ & $3^{* *}$ & 5 & 40 \\
\hline K25.4-SC & 3 & 5 & 3 & 5 & 5 & 40 \\
\hline K26.4-SC & $3 * *$ & 5 & 5 & 3 & 5 & 40 \\
\hline K26.15-SC* & 5 & $3^{* *}$ & 2 & 3 & 5 & 60 \\
\hline K26.8-SC* & 5 & 5 & 5 & 5 & 5 & 0 \\
\hline K7.1-SC & 5 & 5 & 5 & 2 & $1 * *$ & 40 \\
\hline SD+INO & 5 & 5 & 5 & 5 & 5 & 0 \\
\hline
\end{tabular}

* ) Nomor tanaman yang diinokulasi pada generasi R1 dan R2. **) Skor gejala pada tanaman R2 zuriat dari galur R1 terpilih yang menunjukkan resistensi terhadap $S$. rolfsii dan menghasilkan polong bernas hampir sama atau lebih banyak daripada tanaman awal yang tidak diinokulasi. Semua tanaman yang tidak diinokulasi (SD-INO dan SC-INO) tidak menunjukkan gejala penyakit (skor gejala=0). 
kacang tanah yang resisten terhadap infeksi S. rolfsii. Hasil ini mengkonfirmasi hasil penelitian sebelumnya (Song et al., 1994; Ahmed et al., 1996; Jayasankar \& Litz, 1998; Jayasankar et al., 2000) bahwa induksi variasi somaklonal dan seleksi in vitro menggunakan filtrat kultur cendawan patogen dapat digunakan untuk mendapatkan varian dengan fenotip toleran atau resisten terhadap penyakit target.

Keragaan Agronomis Tanaman R2 dengan dan tanpa Inokulasi $S$. rolfsii. Rataan tinggi tanaman (TT), jumlah cabang utama (JCU), jumlah polong cipo (JPC), dan jumlah polong bernas (JPB) per tanaman diantara tanaman awal (kacang tanah cv. Kelinci, SD) dan tanaman R2 zuriat tanaman R0 hasil seleksi in vitro tanpa inokulasi (SC), atau setelah diinokulasi dengan S. rolfsii (SC+INO) disajikan pada Gambar 1. Pada Gambar 1 terlihat bahwa rataan tinggi tanaman dan jumlah polong cipo diantara somaklon R2 zuriat galur $\mathrm{R} 1$ terpilih tanpa inokulasi (SC) atau setelah diinokulasi
(SC+INO) sedikit lebih tinggi daripada rataan tinggi tanaman awal (SD). Sebaliknya, rataan jumlah cabang utama hampir sama antara tanaman awal dengan tanaman somaklon R2 tanpa inokulasi, dan sedikit lebih rendah pada tanaman somaklon $\mathrm{R} 2$ setelah diinokulasi $S$. rolfsii. Rataan jumlah polong bernas somaklon R2 tanpa inokulasi sedikit lebih rendah dibandingkan dengan tanaman awal, sedangkan rataan jumlah polong bernas pada tanaman somaklon R2 setelah diinokulasi lebih rendah dari tanaman awal maupun somaklon tanpa inokulasi. Walaupun secara umum rataan jumlah polong bernas pada somaklon R2 yang diinokulasi lebih rendah daripada tanaman awal atau somaklon R2 yang tidak diinokulasi, namun beberapa nomor somaklon R2 setelah diinokulasi menghasilkan polong bernas yang sama atau lebih banyak dibandingkan dengan tanaman yang tidak diinokulasi (Gambar 2). Nomor-nomor tanaman R2 ini setelah diinokulasi dan diamati menunjukkan keragaman sebagai somaklon yang lebih resisten infeksi $S$. rolfsii.

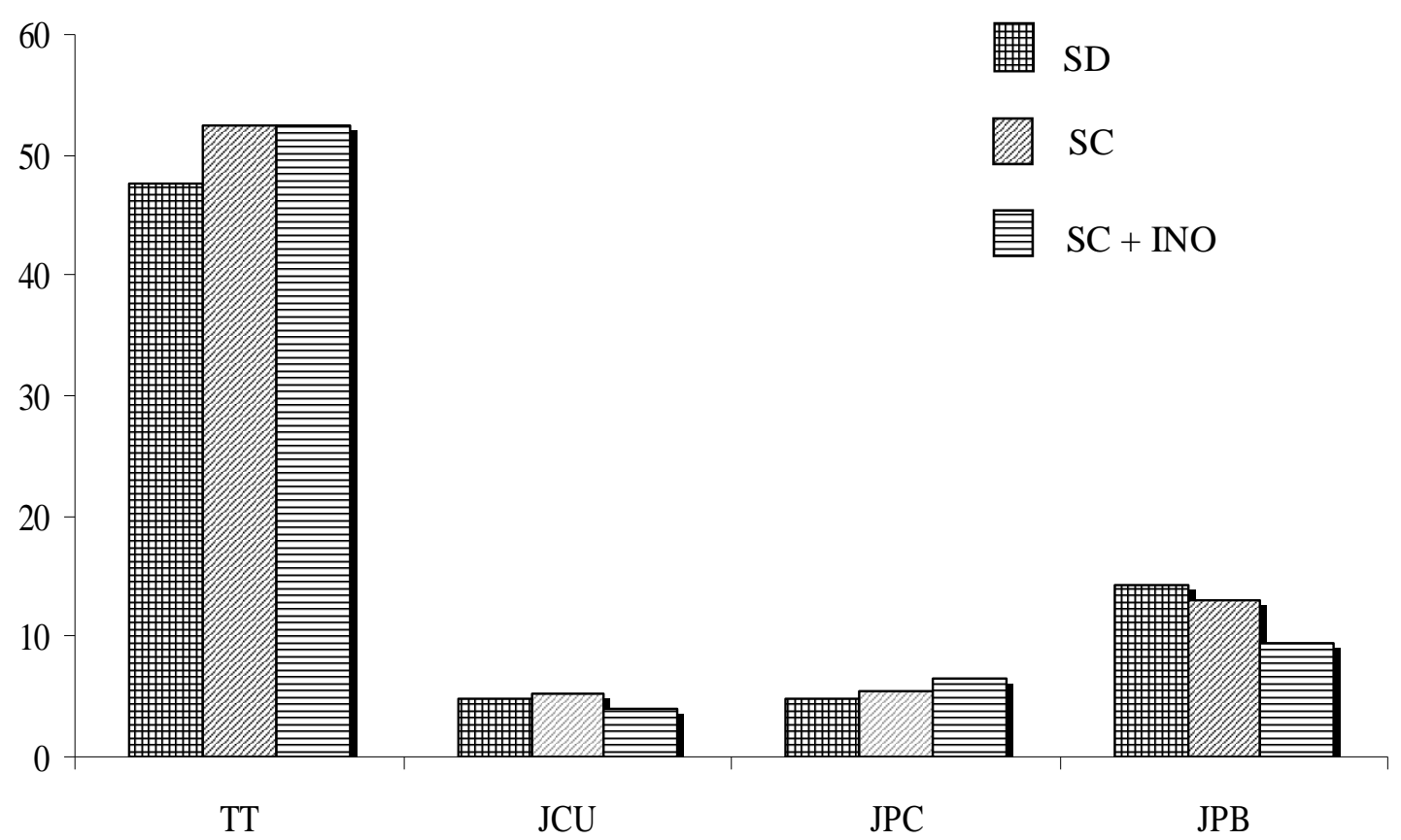

Gambar 1. Rataan tinggi tanaman (TT - cm), jumlah cabang utama (JCU), jumlah polong cipo (JPC), dan jumlah polong bernas (JPB) per tanaman diantara tanaman awal (kacang tanah cv. Kelinci, SD) dan tanaman R2, zuriat tanaman R0 yang diregenerasikan dari ES insensitif filtrat kultur cendawan hasil seleksi in vitro tanpa perlakuan inokulasi (SC), atau setelah diinokulasi dengan $S$. rolfsii (SC+INO) 
Keragaman tanaman somaklon kacang tanah yang tidak diinokulasi dan somaklon yang diinokulasi tetapi masih mampu menghasilkan polong bernas dengan gejala proses penyembuhan luka disajikan pada Gambar 3. Gambar 3a menunjukkan pangkal batang yang tidak bergejala karena tidak diinokulasi. Jumlah polong bernas yang dihasilkan cukup banyak. Gambar 3b-d adalah tanaman somaklon kacang tanah yang terinfeksi $S$. rolfsii. Tanaman terinfeksi ini pada awal perkembangan infeksinya terjadi lesio di pangkal batang, tetapi seiring dengan pertumbuhan dan perkembangan tanaman hingga panen terjadi proses penyembuhan luka dengan terbentuknya kalus dan tanaman tersebut mampu menghasilkan polong bernas dalam jumlah hampir sama dengan tanaman yang tidak diinokulasi.

Penggolongan toleran atau resisten suatu tanaman terhadap penyakit pada umumnya didasarkan atas produktivitas, dalam hal ini jumlah polong bernas per tanaman yang dihasilkan, relatif terhadap rataan jumlah polong bernas tanaman awal yang tidak diinokulasi. Hasil pengamatan menunjukkan bahwa setidaknya sebanyak 20 tanaman (Gambar 2) setelah diinokulasi $S$. rolfsii menghasilkan jumlah polong bernas per tanaman hampir sama atau lebih banyak daripada rataan tanaman awal yang tidak diinokulasi, sehingga dapat digolongkan sebagai resisten. Rataan jumlah polong bernas per tanaman awal yang tidak diinokulasi berjumlah 14,3 sedangkan pada ke-20 somaklon tersebut jumlah polong bernas berkisar antara 13 hingga 22 . Namun demikian, tampaknya penggolongan karakter resisten dan toleran pada somaklon R1 dan R2 yang menghasilkan gejala penyakit dengan skor 1-3 setelah diinokulasi $S$. rolfsii dalam penelitian ini mempunyai kelemahan, karena adanya kemungkinan bahwa karakter kuantitatif mutan tersebut (jumlah polong bernas) pada generasi R1 dan R2 masih belum stabil. Dengan demikian, nomor galur resisten dengan skor gejala penyakit 1-3 yang pada generasi $\mathrm{R} 1$ dan R2 menghasilkan sedikit polong, kemungkinan masih dapat membentuk polong bernas dalam jumlah banyak pada generasi berikutnya.

Adanya segregasi pada populasi R1 dan R2 untuk karakter rentan (skor 5) dan toleran atau resisten (skor 1-3) setelah diinokulasi dengan $S$. rolfsii mengindikasikan bahwa karakter resistensi pada somaklon generasi R0 (tetua tanaman R1) dan generasi
R1 (tetua tanaman R2) dikendalikan oleh gen mutan heterozigot. Karakter resistensi terhadap penyakit busuk batang Sclerotium diduga terjadi karena terjadinya mutasi pada somaklon yang diregenerasikan dari ES yang sebelumnya dipelihara dalam kultur selama lebih dari satu tahun dan dilakukan seleksi in vitro menggunakan filtrat kultur $S$. rolfsii.

\section{Induksi Variasi Somaklonal dan Seleksi In Vitro} Efektif untuk Mendapatkan Tanaman Resisten Penyakit Busuk Batang. Dalam penelitian ini, tampak bahwa sebagian besar zuriat galur R0 menghasilkan mutan resisten penyakit busuk batang Sclerotium. Hanya galur R0 nomor K9-SC saja yang populasi zuriat R2-nya semuanya mati. Hal ini mengindikasikan bahwa penggunaan kultur ES yang telah berumur satu tahun dan seleksi in vitro dengan filtrat kultur $S$. rolfsii merupakan paduan yang efektif untuk menghasilkan ES yang insensitif terhadap agensia penyeleksi, dan ekspresi fenotipe pada level sel paralel dengan ekspresi pada level tanaman utuh generasi R0, R1 dan R2. Dengan kata lain, agensia penyeleksi yang digunakan untuk seleksi in vitro terbukti efektif menghasilkan ES dan somaklon yang resisten terhadap penyakit target. Dalam penelitian terdahulu, filtrat kultur cendawan Fusarium solani juga efektif digunakan sebagai agensia penyeleksi dalam seleksi in vitro ES kedelai dan menghasilkan somaklon resisten (Jin et al., 1996). Jayasankar et al. (2000) juga menggunakan filtrat kultur cendawan Elsinoe ampelina untuk agensia penyeleksi dalam seleksi in vitro Vitis vinifera 'Chardonnay', dan tanaman regeneran menunjukkan gejala resistensi terhadap penyakit antraknosa.

Mekanisme ketahanan somaklon terhadap infeksi S. rolfsii yang terjadi dalam percobaan ini tampaknya bukan merupakan reaksi hipersensitif yang merupakan reaksi cepat, tetapi cenderung pada terjadinya proses lignifikasi dan pembentukan kalus pada bagian batang yang terinfeksi, seiring dengan mengeringnya miselia cendawan di sekitar lesio. Hal ini mengingat bahwa pada awalnya, nekrosis dan lesio pada pangkal batang sudah terjadi dan sempat meluas hingga melingkari seluruh batang (skor 3), namun pada perkembangan selanjutnya miselia cendawan lama kelamaan mengering dan terjadi proses penyembuhan luka (Gambar 3b-d). 

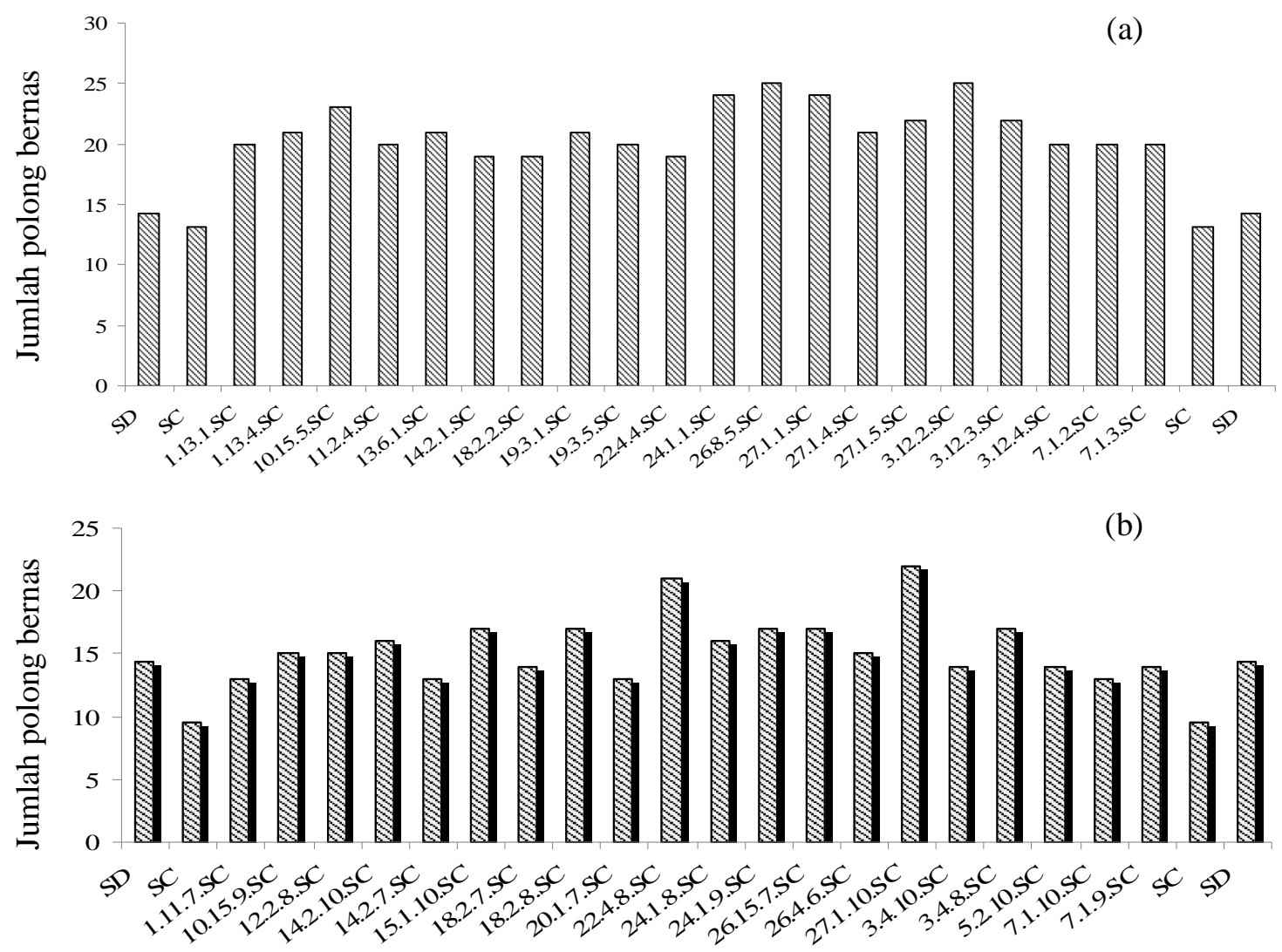

Gambar 2. Representasi jumlah polong bernas dari kacang tanah cv. Kelinci (tanaman awal tanpa inokulasi, SD), rataan semua tanaman somaklon R2 yang diuji (SC), dan individu tanaman R2 yang jumlah polong bernasnya tertinggi. (a) tanpa inokulasi cendawan dan (b) setelah diinokulasi dengan $S$. rolfsii
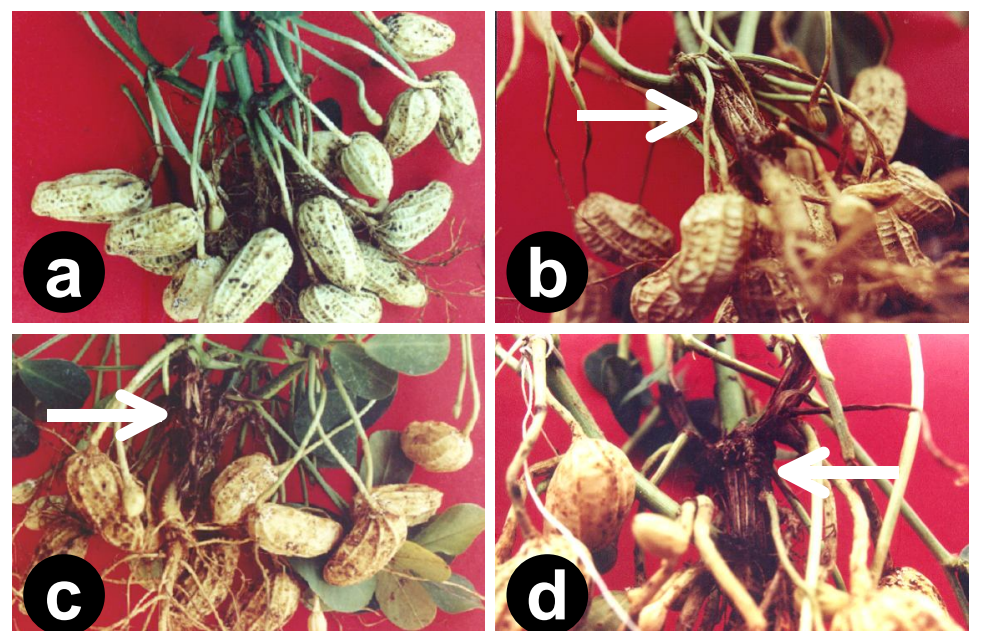

Gambar 3. Contoh tanaman somaklon yang tidak diinokulasi dan diinokulasi dengan S. rolfsii. (a) Pangkal batang tidak menunjukkan gejala penyakit, sehingga tidak terdapat lesio. (b, c, dan d) Contoh tanaman terinfeksi yang pada tahap perkembangannya menunjukkan proses penyembuhan luka (anak panah), yang ditandai dengan terbentuknya kalus. Tanaman-tanaman ini mampu menghasilkan polong bernas dalam jumlah cukup banyak 
Faktor Patogenisitas $S$. rolfsii dan Kemungkinan Mekanisme Resistensi. Dalam proses patogenesisnya, $S$. rolfsii menyintesis dan mensekresikan fitotoksin asam oksalat (OA) dalam jumlah besar (konsentrasi milimolar) dan enzim pendegradasi dinding sel seperti endo-poligakturonase (endo-PG) dan selulase ke dalam jaringan yang terinfeksi. OA menyebabkan $\mathrm{pH}$ asam pada jaringan tanaman, sehingga optimum bagi aktivitas enzim endoPG. Di samping itu, OA mampu mengkelat $\mathrm{Ca}^{++}$dari dinding sel, sehingga sel dan jaringan tanaman inang menjadi sangat rentan terhadap enzim pendegradasi dinding sel yang dikeluarkan oleh cendawan (Rowe, 1993). OA juga dapat menghambat aktivitas $O$-diphenol oxidase, sehingga menghambat oxidative burst (Cessna et al., 2000). Penghambatan oxidative burst dapat menyebabkan reaksi hipersensitif tidak terjadi. Pentingnya OA dalam proses patogenesis juga telah ditunjukkan oleh adanya mutan cendawan $S$. sclerotiorum yang tidak dapat menyintesis OA, dan ternyata mutan cendawan tersebut tidak virulen, sementara cendawan wild-type dan mutan revertantnya dapat menyebabkan penyakit busuk batang pada Phaseolus vulgaris L (Jamaux et al., 1995).

Dalam penelitian ini, somaklon kacang tanah yang resisten terhadap $S$. rolfsii yang didapat merupakan zuriat dari galur-galur R0 yang diregenerasikan dari ES yang insensitif terhadap filtrat kultur cendawan yang diasumsikan mengandung OA. Filtrat tersebut tidak mengandung enzim pendegradasi dinding sel, karena biakan cendawan telah disterilkan dengan autoklaf. Dengan demikian, diduga mekanisme pertahanan yang terjadi di dalam somaklon resisten $S$. rolfsii tentunya disebabkan oleh detoksifikasi OA.

Strategi yang umum digunakan untuk menjadikan suatu tanaman resisten terhadap cendawan patogen yang mensekresikan OA adalah dengan mendegradasi OA tersebut pada saat awal terjadinya infeksi (Lu, 2003). Terdapat tiga kelas enzim yang dikenal dapat berfungsi dalam katabolisme OA, yaitu oxalate oxidase $(\mathrm{OXO})$ (Lane et al., 1991), oxalate decarboxylase (Mehta \& Datta, 1991), dan oxalyl-CoA decarboxylase (Lung et al., 1994). Gen penyandi oxalyl-CoA decarboxylase dari bakteri dapat digunakan untuk mendegradasi OA dan merekayasa tanaman transgenik yang resisten Sclerotinia sclerotiorum (Dickman \& Mitra, 1992), tetapi enzim oxalate decarboksylase yang berasal dari cendawan maupun bakteri bekerja dengan mengubah OA menjadi $\mathrm{CO}_{2}$ dan asam format yang dapat meracuni tanaman (Lu, 2003). Oleh karena itu, para peneliti telah memfokuskan perhatian pada enzim OXO, yang mengubah $\mathrm{OA}$ dan $\mathrm{O}_{2}$ menjadi $\mathrm{CO}_{2}$ dan $\mathrm{H}_{2} \mathrm{O}_{2}$. Sejauh ini, tanaman yang sudah diketahui mempunyai aktivitas enzim OXO adalah gandum, barley, jagung, oat, padi, rye dan cemara (Dunwell et al., 2000).

Dengan mengasumsikan bahwa tanaman kacang tanah juga mempunyai gen penyandi enzim OXO sebagaimana tanaman lain di atas, maka kemungkinan tanaman somaklon resisten kacang tanah yang didapatkan dalam penelitian ini telah mengalami over ekspresi enzim OXO setelah mengalami seleksi in vitro dengan filtrat kultur $S$. rolfsii yang mengandung OA pada konsentrasi tinggi. Over-ekspresi suatu produk gen tertentu mungkin terjadi pada mutan tanaman tertentu. Hal ini dapat disebabkan oleh tidak aktifnya trans-acting factor yang semula menghambat aktivitas enzim OXO karena telah terjadi mutasi titik atau insertional inactivation pada sekuen gen penyandinya. Kemungkinan yang lain, telah terjadi duplikasi sekuen gen penyandi OXO karena terjadi chromosom rearrangengement. Perubahan genetik yang mendasari terjadinya variasi somaklonal meliputi mutasi titik (single nucleotide changes), perubahan jumlah kopi gen tertentu, aktivasi transposable element, perubahan jumlah kromosom, chromosomal rearrangenements, dan metilasi DNA (Larkin \& Scowcroft, 1981; Hammerschlag, 1992).

\section{KESIMPULAN}

Dari penelitian ini telah didapatkan beberapa galur somaklon kacang tanah zuriat dari somaklon R0 yang resisten terhadap infeksi $S$. rolfsii. Sifat resistensi ini terdapat diantara populasi somaklon R1 dan R2, yang bersegregasi antara resisten dan rentan terhadap infeksi $S$. rolfsii. Somaklon kacang tanah yang resisten terhadap infeksi $S$. rolfsii pada awalnya menunjukkan gejala penyakit busuk batang dengan skor antara 1-3, tetapi dalam perkembangannya tanaman menunjukkan proses penyembuhan luka pada lesio, dan tanaman mampu menghasilkan polong bernas yang sama atau lebih banyak dibandingkan tanaman kacang tanah awal yang tidak diinokulasi. 


\section{DAFTAR PUSTAKA}

Ahmed KZ, Mesterhazy A, Bartok T \& Sagi F. 1996. In vitro techniques for selecting wheat (Triticum aestivum L.) for Fusarium-resistance. II. Culture filtrate technique and inheritance of Fusariumresistance in the somaclones. Euphytica 91: 341349.

Cessna SG, Sears VE, Dickman MB \& Low PS. 2000. Oxalic acid, a pathogenicity factor for Sclerotinia sclerotiorum, supresses the oxidative burst of the host plant. Plant Cell 12: 2191-2200.

Daub M. 1986. Tissue culture and the selection of resistance to pathogens. Ann. Rev. Phythopathol. 24: $159-186$.

Dickman MB \& Mitra A. 1992. Arabidopsis thaliana as model for studying Sclerotinia sclerotiorum pathogenesis. Physiol. Mol. Plant Pathol. 41: 255-263.

Dunwell JM, Khuri S \& Gane PJ. 2000. Microbial relatives of the seed storage proteins of higher plants: Conservation of structure and diversivication of function during evolution of the cupin superfamily. Microbiol. Mol. Biol. Rev. 64: 153-179.

Hammerschlag FA. 1992. Somaclonal variation. Pp. 3555 In: Hammerschlag FA \& Litz RE (ed). Biotechnology of Perennial Fruit Crops. Walingford: $\mathrm{CAB}$ International.

Jamaux I, Gelie B \& Lamarque C. 1995. Early stages of infection of rapeseed petals and leaves by Sclerotinia sclerotiorum revealed by scanning electron microscopy. Plant Pathol. 44: 22-30.

Jayasankar S, Li Z \& Gray DJ. 2000. In vitro selection of Vitis vinifera 'Chardonay' with Elsinoe ampelina culture filtrate is accompanied by fungal resistance and enhanced secretion of chitinase. Planta 211: 200-208.
Jayasankar S \& Litz RE. 1998. Characterization of embryogenic mango cultures selected for resistance to Colletotrichum gloeosporoides culture filtrate and phytotoxin. Theor. Appl. Gen. 96: 823-831.

Jin H, Hartman GL, Huang YH, Nickell CD \& Widholm JM. 1996. Regeneration of soybean plants from embryogenic suspension cultures treated with toxic culture filtrate of Fusarium solani and screening of regeneraants for resistance. Phytopathol. 86: 714-718.

Lane BG, Bemier F, Dratewka-Kos E, Shafai R, Kennedy TD, Pyne C, Munro Jr, Vaughan T, Walters D \& Altomare F. 1991. Homologies between members of the germins gene family in hexaploid wheat and similarities between these wheat germins and certain Physarum spherulins. J. Biol. Chem. 266: 10461-10469.

Larkin PJ \& Scowcroft WR. 1981. Somaclonal variation-a novel source of variability from cell cultures for plant improvement. Theor. Appl. Gen. 60: 197-214.

Lu G. 2003. Engineering Sclerotinia sclerotiorum resistance in oil seed crops. African J. Biotech 2: 509-516.

Lung HY, Baetz AL \& Peck AB. 1994. Molecular cloning, DNA sequence, and gene expression of the oxalyl-coenzyme A decarboxylase gene, oxo from the bacterium Oxalobacter formigenes. $J$. Bacteriol. 176: 2468-2472.

Mehta A \& Datta A. 1991. Oxalate decarboxilase from Collybia velutipes: purification, characterization, and cDNA cloning. J. Biol. Chem. 266: 2354823553.

Murashige T \& Skoog F. 1962. A revised medium for rapid growth and bioassays with tobacco tissue cultures. Physiol. Plant 15: 473-497. 
Punja ZK, Huang JS \& Jenkins SF. 1985. Relationship of mycelial growth and production of oxalic acid and cell wall degrading enzymes to virulence in Sclerotium rolfsii. Can J. Plant Pathol. 7: 109117.

Rani I. 2001. Tingkat ketahanan beberapa varietas kacang tanah terhadap Sclerotium rolfsii Sacc. Skripsi. Bogor: Institut Pertanian Bogor.

Rowe DE. 1993. Oxalic acid effects in exudates of Sclerotinia trifoliorum and Sclerotinia sclerotiorum and potential use in selection. Crop Sci. 33: 1146-1149.

Song HS, Lim SM \& Widholm JM. 1994. Selection and regeneration of soybean resistant to patho-toxic culture filtrate of Septoria glycines. Phytopathol. 84: 948-951.
Widyanti. 2001. Uji daya hasil dan respons terhadap penyakit dari berbagai kacang tanah unggul nasional. Skripsi. Bogor: Institut Pertanian Bogor.

Yusnita \& Sudarsono. 2004. Metode inokulasi dan reaksi ketahanan 30 genotipe kacang tanah terhadap penyakit busuk batang Sclerotium. Hayati 11: 53-58.

Yusnita, Widodo \& Sudarsono. 2005. In vitro selection of peanut somatic embryos (SE) on medium containing culture filtrates of Sclerotium rolfsii and plantlet regeneration. Hayati 12: 50-56.

Yusnita, Megia R, Widodo, Aswidinnoor H \& Sudarsono, 2006. Identifikasi Dini Galur Kacang Tanah yang Toleran terhadap Infeksi Sclerotium rolfsii Hasil Seleksi In Vitro dengan Filtrat Kultur Cendawan. Jurnal Hama dan Penyakit Tumbuhan Tropika 6: 41-51. 